\title{
the iolva
} revielv

Spring 1971

$\$ 1.50$

\section{Poems}

2nd

Stories

Criticism

\author{
Jon Anderson \\ John Batki \\ James Crenner \\ Ralph Dickey \\ William Dickey \\ Patricia Goedicke \\ Denis Johnson \\ Philip Levine \\ Morton Marcus \\ Howard McCord \\ W. S. Merwin \\ David Schloss \\ William Stafford \\ Robert Sward

\section{Ann Cameron Harvey Joyce Carol Oates \\ Jack Matthews \\ Ursule Molinaro}

Calvin Bedient On Donald Davie (three poems by Davie)

William H. Pritchard

Wyndham Lewis and Lawrence

Frederic Will

Translation and Criticism

(a poem by Fernando Retamar

Tr: Arbelaez and Will)

(a poem by Fayad Jamis

Tr: Arbelaez and Will)

Roy Harvey Pearce

The Burden of Romanticism: Toward the New Poetry 


\section{the iolva revielv}

Volume 2 Number 2

Spring 1971

Contents

\begin{tabular}{llr}
\hline POETRY & Rosebud & 4 \\
& A Descent & 6 \\
James Crenner & Failure & 7 \\
Ralph Dickey & Lockjaw & 8 \\
& Father & 9 \\
William Dickey & In the Days of the Fall of the Empire & 10 \\
Patricia Goedicke & My Mother's/My/Death/Birthday & 11 \\
Denis Johnson & There Are Trains Which Will Not Be & \\
& Missed & 12 \\
& What This Window Opens On & 13 \\
Philip Levine & Cry for Nothing & 14 \\
Morton Marcus & from: The Santa Cruz Mountain Poems & 16 \\
Howard McCord & Oh, & 17 \\
David Schloss & The Adulteress & 18 \\
& A Bus & 20 \\
W. S. Merwin & Sibyl & 22 \\
William Stafford & Speaking Frankly & 23 \\
John Batki & Traders & 24 \\
& Wishes on a Blue Afternoon & 25 \\
Robert Sward & Who's Wilder, Who's More Mystical? & 26
\end{tabular}

$\begin{array}{ll}\text { Fiction } & \text { Ann Cameron Harvey } \\ & \text { Joyce Carol Oates } \\ & \text { Jack Matthews } \\ & \text { Ursule Molinaro }\end{array}$

A Short Dance 28

The Turn of the Screw 36

A Genealogy of Trees and Flesh $\quad 49$

Prayerwheels Up \& Down a Glorified

14th Street o Beyond

\section{CRITICISM Calvin Bedient \\ William H. Pritchard Frederic Will}

Roy Harvey Pearce
On Donald Davie

(three poems by Davie)

Wyndham Lewis and Lawrence $\quad 91$

Translation and Criticism $\quad 97$

(a poem by Fernando Retamar tr: Arbelaez and Will)

(a poem by Fayad Jamis

tr: Arbelaez and Will)

The Burden of Romanticism: Toward the New Poetry
66

109

Next Issue

Notes on Contributors 
The Iowa Review is a literary quarterly sponsored and published by the School of Letters and the Graduate College of The University of Iowa and printed by The University of Iowa Printing Service.

Copyright (C) 1971, by The University of Iowa.

Second class postage paid at Iowa City, Iowa 52240.

Price: $\$ 6.00$ a year, $\$ 11.00$ for two years, $\$ 16.00$ for three years, in the United States, Canada and Mexico. Elsewhere, one dollar per year additional.

Send subscriptions to the Department of Publications, The University of Iowa, Iowa City, Iowa 52240.

Manuscripts should be sent, with a self-addressed, stamped envelope, to The Iowa Review, EPB 453, The University of Iowa, Iowa City, Iowa 52240.

Merle E. Brown, Editor

Marvin Bell, Poetry Editor

Wilfrido D. Nolledo, Fiction Editor

Editorial Assistants:

Susan Aukema

Jane Cogie

Neil Ruddy

Norman Sage, Business Manager

Irwin McFadden, Designer 


\title{
poetry
}

\author{
Jon Anderson \\ John Batki \\ James Crenner \\ Ralph Dickey \\ William Dickey \\ Patricia Goedicke \\ Denis Johnson \\ Philip Levine \\ Morton Marcus \\ Howard McCord \\ W. S. Merwin \\ David Schloss \\ William Stafford \\ Robert Sward
}




\section{fiction}

Ann Cameron Harvey

Joyce Carol Oates

Jack Matthews

Ursule Molinaro 


\section{the seneca review}

Spring 1971 Issue (volume two, number one)

Featuring an Interview with and New Poems by

Donald Justice

New Poems By:

ROBERT MEZEY

LUCIEN STRYK

ALVIN GREENBERG

GREG KUZMA

BRIAN SWANN

MARK MCCLOSKEY

and others
New Translations Of :

PABLO NERUDA

CESAR VALLEJO

PAUL ELUARD

ROBERT DESNOS

WOLFGANG BORCHERT

Some Copies of our first two issues are still available

Featuring the Work of :

Robert Bly David Ignatow William Matthews

W. S. Merwin Charles Simic Nancy Willard

R. V. Cassill James Tate Peter Wild

Stephen Berg Frederick Busch Charles Aukema

SUBSCRIPTIONS

$\$ 2.00$ year $\$ 3.50$ two years

All mss. must be accompanied

by s.a.s.e.
Address all correspondence to: THE SENECA REVIEW

Box 115

Hobart \& Wm. Smith Colleges Geneva, N. Y. 14456 


\section{criticism}

Calvin Bedient On Donald Davie (three poems by Davie)

William H. Pritchard

Wyndham Lewis and Lawrence

Frederic Will

Translation and Criticism

(a poem by Fernando Retamar

Tr: Arbelaez and Will)

(a poem by Fayad Jamis

Tr: Arbelaez and Will)

Roy Harvey Pearce

The Burden of Romanticism:

Toward the New Poetry 